\title{
Increased amyloidogenic processing of transgenic human APP in X11-like deficient mouse brain
}

\author{
Maho Kondo ${ }^{1 \dagger}$, Maki Shiono ${ }^{1 \dagger}$, Genzo Itoh ${ }^{2}$, Norio Takei ${ }^{1,2}$, Takahide Matsushima ${ }^{1}$, Masahiro Maeda ${ }^{2,3}$, \\ Hidenori Taru ${ }^{4,5}$, Saori Hata', Tohru Yamamoto', Yuhki Saito ${ }^{1}$, Toshiharu Suzuki ${ }^{1 *}$
}

\begin{abstract}
Background: X11-family proteins, including X11, X11-like (X11L) and X11-like 2 (X11L2), bind to the cytoplasmic domain of amyloid $\beta$-protein precursor (APP) and regulate APP metabolism. Both $X 11$ and $X 11 \mathrm{~L}$ are expressed specifically in brain, while X11L2 is expressed ubiquitously. X11L is predominantly expressed in excitatory neurons, in contrast to $X 11$, which is strongly expressed in inhibitory neurons. In vivo gene-knockout studies targeting X11, $\mathrm{X} 11 \mathrm{~L}$, or both, and studies of $\mathrm{X} 11$ or $\mathrm{X} 11 \mathrm{~L}$ transgenic mice have reported that $\mathrm{X} 11$-family proteins suppress the amyloidogenic processing of endogenous mouse APP and ectopic human APP with one exception: knockout of $\mathrm{X} 11, \mathrm{X} 11 \mathrm{~L}$ or $\mathrm{X} 11 \mathrm{~L} 2$ has been found to suppress amyloidogenic metabolism in transgenic mice overexpressing the human Swedish mutant APP (APPswe) and the mutant human PS1, which lacks exon 9 (PS1dE9). Therefore, the data on X11-family protein function in transgenic human APP metabolism in vivo are inconsistent.
\end{abstract}

Results: To confirm the interaction of $X 11 \mathrm{~L}$ with human APP ectopically expressed in mouse brain, we examined the amyloidogenic metabolism of human APP in two lines of human APP transgenic mice generated to also lack $\mathrm{X} 11 \mathrm{~L}$. In agreement with previous reports from our lab and others, we found that the amyloidogenic metabolism of human APP increased in the absence of X11L.

Conclusion: $\mathrm{X} 11 \mathrm{~L}$ appears to aid in the suppression of amyloidogenic processing of human APP in brain in vivo, as has been demonstrated by previous studies using several human APP transgenic lines with various genetic backgrounds. X11L appears to regulate human APP in a manner similar to that seen in endogenous mouse APP metabolism.

\section{Background}

X11 proteins (X11s) comprise a family of three adaptor proteins in mammals: X11 (X11/X11 $\alpha /$ Mint1), X11-like

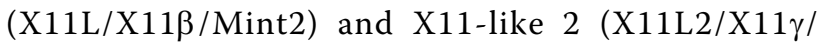
Mint3) [1]. These molecules are evolutionally conserved in D. melanogaster [2,3] and C. elegans [4]. In mammals, $\mathrm{X} 11$ and $\mathrm{X} 11 \mathrm{~L}$ are expressed predominantly in neurons, while X11L2 is expressed ubiquitously [reviewed in ref. [5]]. X11s associate with the cytoplasmic domain of amyloid $\beta$-protein precursor (APP) and suppress APP metabolism, including amyloid $\beta$-protein $(\mathrm{A} \beta)$ generation $[1,6,7]$, which is widely believed to be the major cause of Alzheimer's disease (AD) pathogenesis [8]. APP

\footnotetext{
* Correspondence: tsuzuki@pharm.hokudai.ac.jp

† Contributed equally

'Laboratory of Neuroscience, Graduate School of Pharmaceutical Sciences, Hokkaido University, Kita12-Nishi6, Kita-ku, Sapporo 060-0812, Japan Full list of author information is available at the end of the article
}

is subjected to alternative cleavages by a combination of $\alpha$ - and $\gamma$-secretases or $\beta$ - and $\gamma$-secretases. Primary cleavage of APP by $\alpha$-secretase is amyloidolytic and generates a C-terminal fragment, CTF $\alpha$, which includes the $C$-terminal half of the $A \beta$ sequence, whereas cleavage by $\beta$-secretase is amyloidogenic and generates CTF $\beta$, which includes an intact $A \beta$ sequence. Both CTF $\alpha$ and CTF $\beta$ are further cleaved by $\gamma$-secretase in the lipid bilayer, resulting in the secretion of the amyloidolytic $\mathrm{p} 3$ fragment from CTF $\alpha$ and the neurotoxic $A \beta$ from CTF $\beta$ [9].

The association of X11s with APP is mediated by interaction between the phosphotyrosine interaction domain (PTB) of X11s and the 681-GYENPTY-687 motif of APP. This association has been shown to greatly suppress the amyloidogenic metabolism of APP in the brain in vivo. Specifically, the production of amyloidogenic CTF $\beta$, but not amyloidolytic CTF $\alpha$, derived from endogenous mouse APP was found to be

\section{() Biomed Central}


enhanced, and accumulation of mouse $A \beta$ was found to be increased, in the brains of X11-knockout, X11Lknockout, and X11 plus X11L double-gene knockout mice [10-12]. Recent evidence indicates that the majority of both $\beta$ - and $\gamma$-secretases are located in cholesteroland sphingolipid-rich detergent-resistant membrane domains (DRM domains or lipid rafts) as active forms $[13,14]$. DRMs in the brains of mice lacking X11 and $\mathrm{X} 11 \mathrm{~L}$ are rich in mature APP $(N$ - and $O$-glycosylated form), the substrate to secretases, and the amyloidogenic metabolite CTF $\beta$ [11]. These observations suggest that $\mathrm{X} 11$ and $\mathrm{X} 11 \mathrm{~L}$ function to form a complex with APP that then remains outside of the DRMs. In this way, they regulate amyloidogenic cleavage of APP through suppression. This suppressive inhibition of human APP amyloidogenic metabolism by $\mathrm{X} 11$ and $\mathrm{X} 11 \mathrm{~L}$ was also confirmed in the brains of X11- or X11L-Tg mice expressing human Swedish mutant APP (APPswe/ Tg2576) [15,16] (Table 1). On the other hand, a controversial report analyzing human APP metabolism in the brains of mice lacking X11s found that the amyloidogenic metabolism of APPswe was suppressed in the brains of mice lacking X11 proteins and constitutively expressing the active PS1 mutant PS1dE9 [17] (Table 1). In this study, we investigated whether the amyloidogenic metabolism of human APP, as well as endogenous mouse APP, is facilitated in murine brains lacking X11L.
We focused on $\mathrm{X} 11 \mathrm{~L}$, rather than $\mathrm{X} 11$, because it is more widely distributed and because it suppresses APP metabolism more strongly [10,11]. Our data showed increased amyloidogenic metabolism in two transgenic mouse lines expressing relatively higher (APP23) and lower (APP-ibl) levels of human APPswe in the absence of $\mathrm{X} 11 \mathrm{~L}$, indicating that $\mathrm{X} 11 \mathrm{~L}$ functions to suppress APP amyloidogenic metabolism in brain in vivo.

\section{Results}

APP metabolism in APP23 mouse brain lacking X11L

The amyloidogenic metabolism of endogenous APP in brain was facilitated in X11-, X11L-, and X11 plus $\mathrm{X} 11 \mathrm{~L}$ - gene knockout mice, while a contrary result was reported for exogenously expressed human APPswe in X11s (X11, X11L or X11L2)- gene knockout mice [17]. $\mathrm{X} 11 \mathrm{~L}$-gene knockout mice have been shown to exhibit more strongly enhanced amyloidogenic metabolism of endogenous APP as compared with X11-gene knockout mice $[10,11]$. Thus, we reexamined the function of $\mathrm{X} 11 \mathrm{~L}$ in the suppression of APP amyloidogenic metabolism using X11L-gene knockout mice and human APPswe transgenic mouse lines.

We first generated APP23 mice lacking X11L because APP23 mice have been established as a transgenic line expressing human APP751swe [18,19], and the expression level of APP in these mice is high enough to allow

Table 1 Effect of X11s in the generation of $A \beta$ in the brains of several transgenic and knock-out mouse lines

\begin{tabular}{|c|c|c|c|c|c|}
\hline $\begin{array}{c}\text { Reference } \\
\text { number in text }\end{array}$ & Authors \& Journal & X11 family genes & APP and PS genes & $\begin{array}{l}\text { Examination of } \\
\text { brain } A \beta \text { levels }\end{array}$ & $\begin{array}{l}\text { Effect of X11s in the } \\
\text { generation of } A \beta\end{array}$ \\
\hline [10] & $\begin{array}{l}\text { Sano et al., } \\
\text { J. Biol. Chem. (2006) } \\
\text { 281, 37853-37860. }\end{array}$ & $\mathrm{X} 11 \mathrm{~L}$, knock-out & $\begin{array}{l}\text { endogenous } \\
\text { mouse APP }\end{array}$ & $\begin{array}{l}\text { mouse } A \beta 40 \\
\text { mouse } A \beta 42\end{array}$ & suppressive \\
\hline [11] & $\begin{array}{l}\text { Saito et al., } \\
\text { J. Biol. Chem. (2008) } \\
\text { 283, 35763-35771 }\end{array}$ & $\begin{array}{l}X 11, X 11 L, \& X 11 / \\
X 11 L, \text { knock-out }\end{array}$ & $\begin{array}{l}\text { endogenous } \\
\text { mouse APP }\end{array}$ & $\begin{array}{l}\text { mouse } A \beta 40 \\
\text { mouse } A \beta 42\end{array}$ & suppressive \\
\hline [15] & $\begin{array}{l}\text { Lee et al., } \\
\text { J. Biol. Chem. (2003) } \\
\text { 278, 47025-47029. }\end{array}$ & $\mathrm{X} 11$, transgenic & $\begin{array}{l}\text { human APPswe } \\
\text { transgenic (Tg2576) }\end{array}$ & $\begin{array}{l}\text { human } A \beta 40 \\
\text { human } A \beta 42\end{array}$ & suppressive \\
\hline [16] & $\begin{array}{l}\text { Lee et al., } \\
\text { J. Biol. Chem. (2004) } \\
\text { 279, 49099-49104. }\end{array}$ & $\mathrm{X} 11 \mathrm{~L}$, transgenic & $\begin{array}{l}\text { human APPswe } \\
\text { transgenic (Tg2576) }\end{array}$ & $\begin{array}{l}\text { human } A \beta 40 \\
\text { human } A \beta 42\end{array}$ & suppressive \\
\hline [17] & $\begin{array}{l}\text { Ho et al., } \\
\text { J. Neurosci. (2008) } \\
28,14392-14400 .\end{array}$ & $\begin{array}{l}\mathrm{X} 11, \mathrm{X} 11 \mathrm{~L} \text { or } \mathrm{X} 11 \mathrm{~L} 2, \\
\text { knock-out }\end{array}$ & $\begin{array}{l}\text { human APPswe/PS1dE9 } \\
\text { double-transgenic }\end{array}$ & $\begin{array}{l}\text { human } A \beta 40 \\
\text { human } A \beta 42\end{array}$ & facilitative \\
\hline [23] & $\begin{array}{l}\text { Saluja et al., } \\
\text { Neurobiol. Dis. (2009) } \\
\text { 36, 162-168. }\end{array}$ & $\begin{array}{l}\text { X11, heterozygous } \\
\text { knock-out }\end{array}$ & $\begin{array}{l}\text { human APPswe/PS1dE9 } \\
\text { double-transgenic }\end{array}$ & $\begin{array}{l}\text { human } A \beta 40 \\
\text { human } A \beta 42\end{array}$ & suppressive \\
\hline [24] & $\begin{array}{l}\text { Mitchell et al., } \\
\text { Hum. Mol. Genet. (2009) } \\
\text { 18, 4492-4500. }\end{array}$ & $\mathrm{X} 11 \mathrm{~L}$, transgenic & $\begin{array}{l}\text { human APPswe } \\
\text { transgenic } \\
\text { (Tg2576) }\end{array}$ & $\begin{array}{l}\text { human } A \beta 40 \\
\text { human } A \beta 42\end{array}$ & suppressive \\
\hline Present results & $\begin{array}{l}\text { Kondo et al., } \\
\text { Mol. Neurodegen. }\end{array}$ & X11L, knock-out & $\begin{array}{l}\text { human APPswe } \\
\text { transgenic } \\
\text { (APP23), } \\
\text { human APPswe } \\
\text { transgenic } \\
\text { (APP-ibl) }\end{array}$ & $\begin{array}{l}\text { human } A \beta 40 \\
\text { human } A \beta 42\end{array}$ & suppressive \\
\hline
\end{tabular}


the observation of amyloid plaques in mice at around 10 months. The overproduction of $A \beta$ is still milder in APP23 than in APPswe-Tg/PS1dE9-Tg, another human APP transgenic mouse model that constitutively overproduces $A \beta$ to grow amyloid plaques at younger ages and has been used in previous analyses $[17,20]$. APP23 may be the better model for precise evaluation of the regulatory role of X11L. We first examined human APPswe expression in the APP23 X11L knockout (APP23/X11L-Ko) mouse brain. The brain regions used included the cerebral cortex, hippocampus and olfactory bulb of wild-type, APP23 and APP23/X11L-Ko mice (56 months old). Membrane (P100) and cytoplasmic (S100) fractions were prepared and analyzed for human APP, human-plus-mouse APP, X11L and flotillin-1 (as a marker for membrane protein) by immunoblotting with respective antibodies (Fig. 1A). We confirmed that the human APP level did not change significantly in APP23 mice lacking X11L (Fig. 1A, first rows; Fig. 1B, left). Using the same samples, we examined the level of amyloidogenic fragment (CTF $\beta / C 99)$ derived from human APP by immunoblotting with anti-human, $A \beta$-specific antibody (Fig. 1A, third rows). Our previous results indicated that CTF $\beta$ (C99) derived from endogenous mouse APP increased in X11L-deficient mouse brains [11]. In agreement with these data, we found that the human CTFß (C99) from APPswe also increased significantly in the brains of APP23/X11L-Ko mice when compared with APP23 mice (Fig. 1A, third rows; Fig. 1B, right).

We further examined secreted human $A \beta$ and human sAPP, large extracellular $\mathrm{N}$-terminal domain truncated at the $\alpha$-site (sAPP $\alpha)$ and/or $\beta$-site (sAPP $\beta)$, levels in the same samples (Figs. 2 and 3). Human $A \beta 40$ and A $\beta 42$ significantly increased in APP23/X11L-Ko mice (Fig. 2). Since the difference between $A \beta 40$ and $A \beta 42$ is dependent on alternative intramembrane $\gamma$-cleavage, we investigated the increase in primary $\beta$-site cleavage by detecting human sAPP $\beta$ swe (Fig. $3 \mathrm{~A}$, third rows). The sAPP $\beta$ swe, derived from human APPswe, was detected by immunoblotting with anti-sAPP $\beta$ swe specific antibody, which showed a significant increase in SAPP $\beta$ swe in APP23/X11L-Ko mice (Fig. 3B, right). The total levels of human SAPP and SAPP $\alpha$ were not significantly altered (Fig. 3A, first and second rows; Fig. 3B, left and middle). These analyses indicate that a lack of X11L facilitates the primary amyloidogenic processing of human APP at the $\beta$-site, but not at the $\alpha$-site, as has been previously shown for the processing of endogenous mouse APP in X11L-Ko mouse brains [11].

If amyloidogenic processing of human APP were to progress in the brains of APP23/X11L-Ko mice, amyloid plaques would be expected to appear at younger ages than is seen in APP23 mice. It has been well established that amyloid plaque formation appears in $~ 10$ month APP23 mice. Thus, we examined the formation of amyloid plaques in both 5, 9 and 12 month mice of APP23 and APP23/X11L-Ko. At five months, amyloid plaques appeared in neither APP23, nor APP23/X11L mice (Additional file 1, Fig. S1), but at nine months, amyloid plaques appeared in both APP23 and APP23/X11L-Ko mice (Additional file 1, Fig. S2). Brain slices of mice (12 months old) were immunostained with anti-human $A \beta$ antibody, the plaque numbers increased remarkably in APP23/X11L-Ko when compared to APP23 (Fig. 4A). The numbers of amyloid plaques in the two lines, APP23 and APP23/X11L-Ko (12 months old), were quantified in 18 serial sections from six individuals (Fig. $4 \mathrm{~B})$. The sections, including the cerebral cortex, the hippocampus and the entorhinal cortex, were analyzed for the plaque numbers. The average number of amyloid plaques was 48.5 per section in APP23/X11L-Ko mice, but only 18.8 per section in APP23 mice, indicating that plaque numbers significantly increase in brains lacking X11L.

Taken together with previous observations that the numbers of amyloid plaques were decreased in the brains of X11- or X11L-tg mice expressing human APPswe [15,16], the present observation indicates that $\mathrm{X} 11 \mathrm{~L}$ plays an important role in the suppression of the amyloidogenic and pathogenic metabolism of human APP, as well as the observation of facilitated amyloidogenic metabolism of endogenous APP in X11-, X11L-, and X11 plus X11L- knockout mice [10,11].

\section{APP metabolism in APP-ibl mouse brain lacking X11L}

The analysis described above was also performed with another APP transgenic mouse line, APP-ibl, which was generated using human APP695swe. In contrast to APP23, which expressed relatively higher levels of human APP751swe, APP-ibl expressed levels of human APP 1.2-1.4 times those of endogenous mouse APP (Fig. $5 \mathrm{~A}$, second rows; Fig. 5B, right). The human APP level was similar between APP-ibl and APP-ibl/X11L-Ko mice brain (Fig. 5A, first rows; Fig. 5B, left), as was observed in APP23 and APP23/X11L-Ko (Fig. 1). The level of the amyloidogenic fragment of human APP, CTF $\beta$ (C99), increased significantly in APP-ibl/X11L-Ko (5-6 months old) when compared to the same age of APP-ibl mice (Fig. 6Aand 6B). We also examined the levels of another CTF $\beta$ (C89) and CTF $\alpha$ (C83), along with CTF $\beta$ (C99), by immunoblotting with pan-APP CTF antibody, which detects both human and mouse CTFs (Fig. 6Cand 6D). Both C99 and C89 CTF $\beta$ levels increased significantly in APP-ibl/X11L-Ko mouse brains, while the levels of CTF $\alpha$ (C83) were the same regardless of X11L expression. The enhanced amyloidogenic metabolism of APP was further confirmed by 


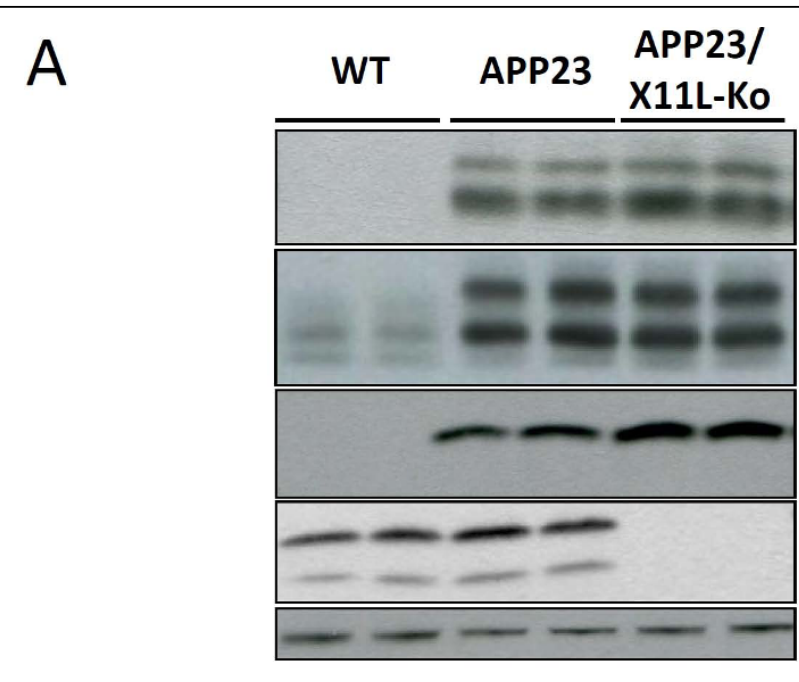

B

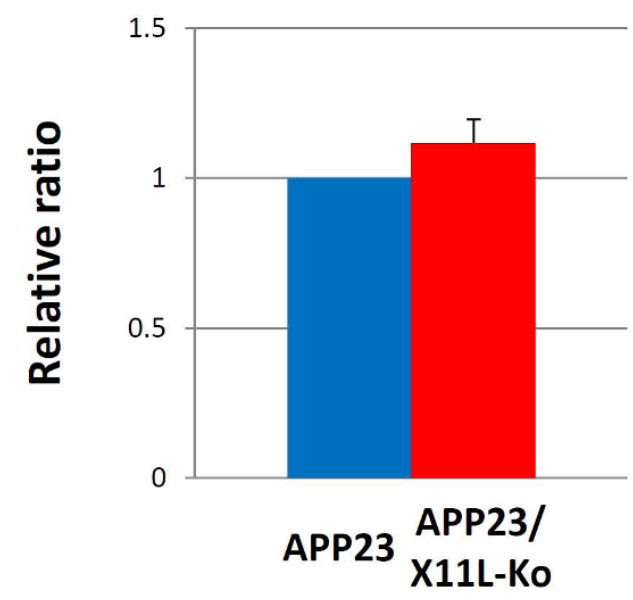

human APP

human \& murine APP

human C99 (CTF $\beta)$

X11L

\section{flotillin-1}

human $C 99$

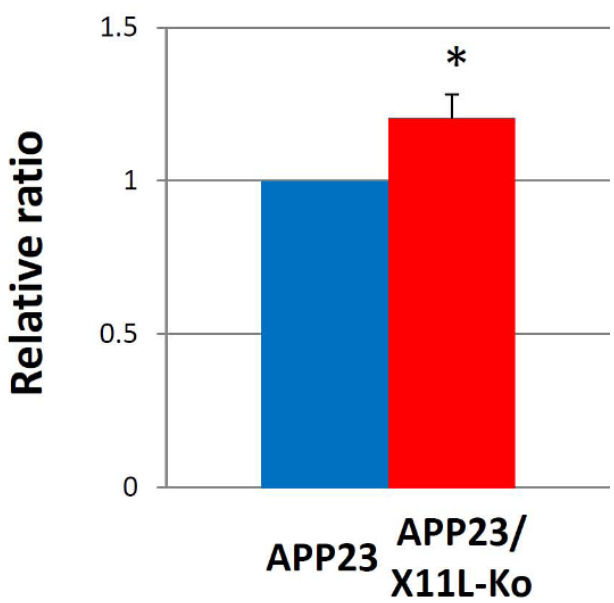

Figure 1 Expression of APP and generation of primary amyloidogenic fragment CTF $\beta$ in APP23 mice in the presence or absence of X11L. (A) Expression of human APP751swe and detection of human CTF $\beta$ (C99) in APP23 mouse brain samples in the presence or absence of $\mathrm{X} 11 \mathrm{~L}$ and in wild-type mice. Membrane (P100 for APP, CTF $\beta$ and flotillin-1) and cytoplasmic (S100 for X11L) fractions of brain regions composed of the cerebral cortex, hippocampus and olfactory bulb from wild-type (WT), APP23 and APP23/X11L-Ko mice (5-6 months old) were analyzed for the expression of transgenic human APP751swe (anti-APP 10D1 antibody), total APP (human APP751swe combined with mouse endogenous APP695, anti-APP/C 8717 antibody), human APP C99 (CTF $\beta$, anti-human A 82 E1 antibody), X11L and flotilin-1 by immunoblotting. For human APP, the upper band indicates mature APP751swe (mAPP) and the lower band indicates immature APP751swe (imAPP). For mouse APP (see lanes of WT), the upper two bands are mAPP695 and lower band is imAPP695. To identify CTF species with or without phosphorylation at Thr668, the lysates were subjected to dephosphorylation prior to detection as described in Materials and Methods (for identification of APP and CTF molecules, reviewed in Suzuki and Nakaya [12]). (B) The densities of human APP751swe (left) and C99 (right) bands were standardized to the density of flotillin-1, which was compared with the ratios for APP23 mice that were assigned a reference value of 1.0 (values represent the means \pm S.E.). The data were analyzed by Student's $t$ test $\left(n=10 ;{ }^{*}, p<0.05\right)$.

quantifying brain $\mathrm{A} \beta$ levels, which increased significantly in APP-ibl/X11L-Ko as compared with APP-ibl mice for both $A \beta 40$ and $A \beta 42$ at 5-6 months of age (Fig. 7). In contrast to the APP23 mice, at 12 months of age, the APP-ibl mice had not generated any amyloid plaques (data not shown). This is probably because the levels of $\mathrm{A} \beta 40$ and $\mathrm{A} \beta 42$ are much lower than those in APP23 mice (1/15-1/20 the levels of APP23 mice) (compare Fig. 2 to Fig. 7 ).

In summary, we used two human APP transgenic mouse lines lacking the $\mathrm{X} 11 \mathrm{~L}$ gene and found that $\mathrm{X} 11 \mathrm{~L}$ functions in the suppression of amyloidogenic metabolism of human APP, as it does for mouse endogenous $\mathrm{APP}$, in brain in vivo. 


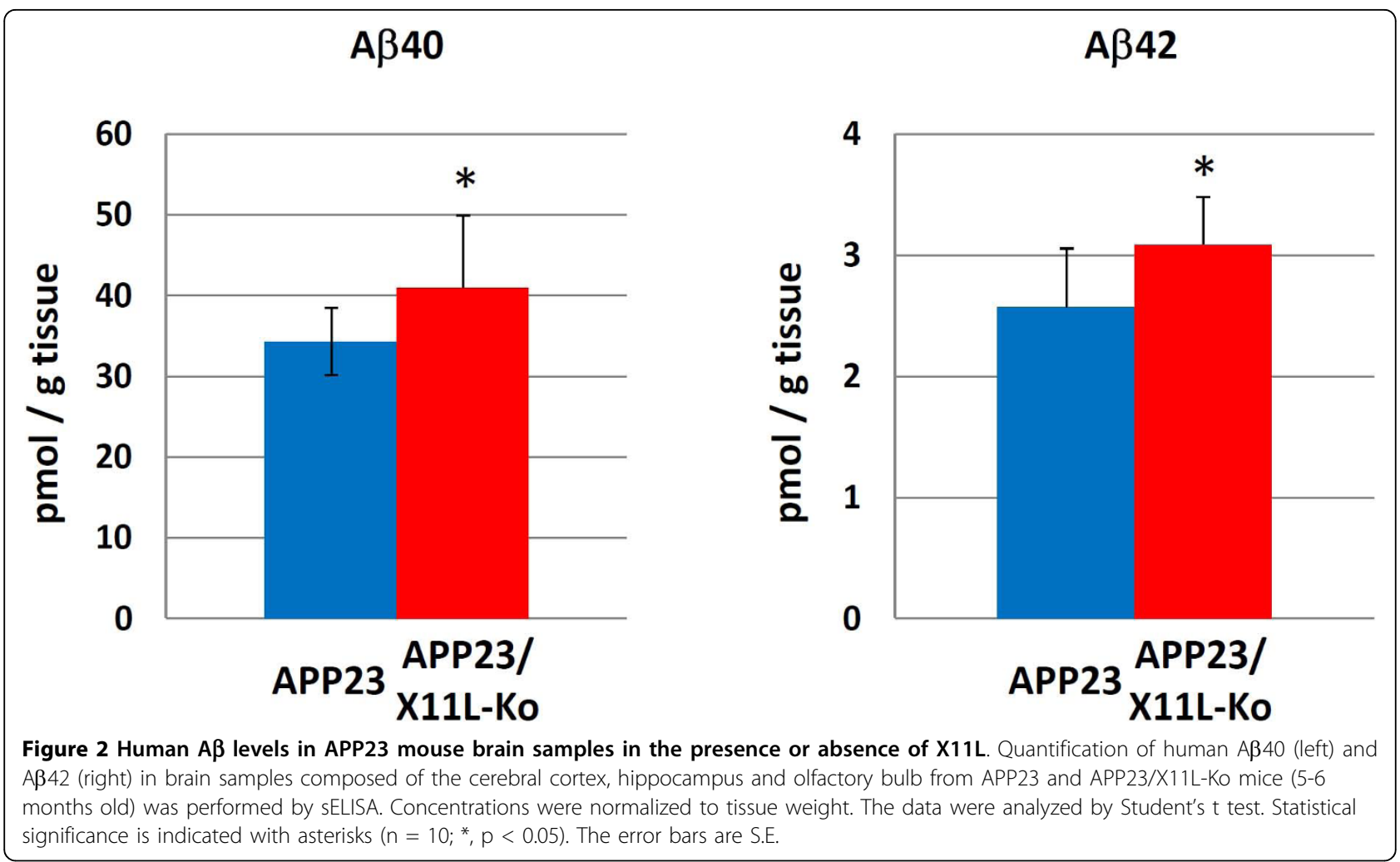

\section{Discussion}

The qualitative and quantitative alteration of $A \beta$ generation is a major cause of AD pathogenesis. Familial Alzheimer's disease (FAD)-linked presenilin-1 mutations increase the longer, pathogenic A $\beta 42$ species. APP locus duplication also induces an increase in $A \beta$ generation. Both of these cases, one showing qualitative and one showing quantitative alteration of $A \beta$ generation, induce early-onset $\mathrm{AD}[8,21,22]$. Because the pathological progression of sporadic AD (SAD) is similar to that of $F A D$, the regulation of $A \beta$ generation (in terms of both quality and quantity) is also important in SAD pathogenesis, regardless of the absence of known causative genetic mutations.

The regulation of APP metabolism is closely related to intracellular protein sorting, in which many regulatory molecules associate directly or indirectly with APP $[9,12]$. The X11 family proteins X11, X11L and X11L2 directly associate with APP through their PTB domains. This protein interaction is thought to regulate the metabolism and intracellular trafficking of APP. In cells expressing APP together with X11, X11L, or X11L2, APP metabolism is remarkably suppressed, with a consequential decrease in $A \beta$ generation [1,6,7]. However, in vitro studies have not been able to fully characterize the molecular function of X11L in APP metabolism in brain. To resolve this issue, several lines of transgenic and knockout mice for X11 genes were produced and used to examine APP metabolism in brain in vivo, including $A \beta$ generation and/or amyloid plaque formation. X11 and X11L transgenic mice expressing human APPswe show decreased levels of cerebral $A \beta$ and reductions in $A \beta$ plaques in comparison with mice expressing APPswe alone $[15,16]$. Furthermore, amyloidogenic metabolism of endogenous mouse APP has been shown to be facilitated in the brains of X11-, X11L- and X11 plus X11L- gene knockout mice [10,11], indicating that X11s function physiologically to suppress the amyloidogenic metabolism of APP. These results have been confirmed by similar studies [23,24], but also conflict with a report that X11s (X11, X11L or X11L2)gene Ko mice overexpressing APPswe and PS1dE9 decreased $A \beta$ generation at younger ages [17].

We consider that the contrary results may be dependent on the presence or absence of mutations in the PS1 gene because PS1 is known to regulate intracellular protein trafficking [25]. Transgenic mice with APPswe and PS1dE9 genes (APPswe/PS1dE9-tg) generate larger amounts of $A \beta$ without intracellular regulation of APP metabolism and trafficking. APPsw/PS1dE9 mice are suitable as an AD model showing AD pathology [20], but may not be suitable for analysis of the regulation of intracellular APP metabolism. Therefore, in this study, we used two lines of X11L-Ko mice expressing human 


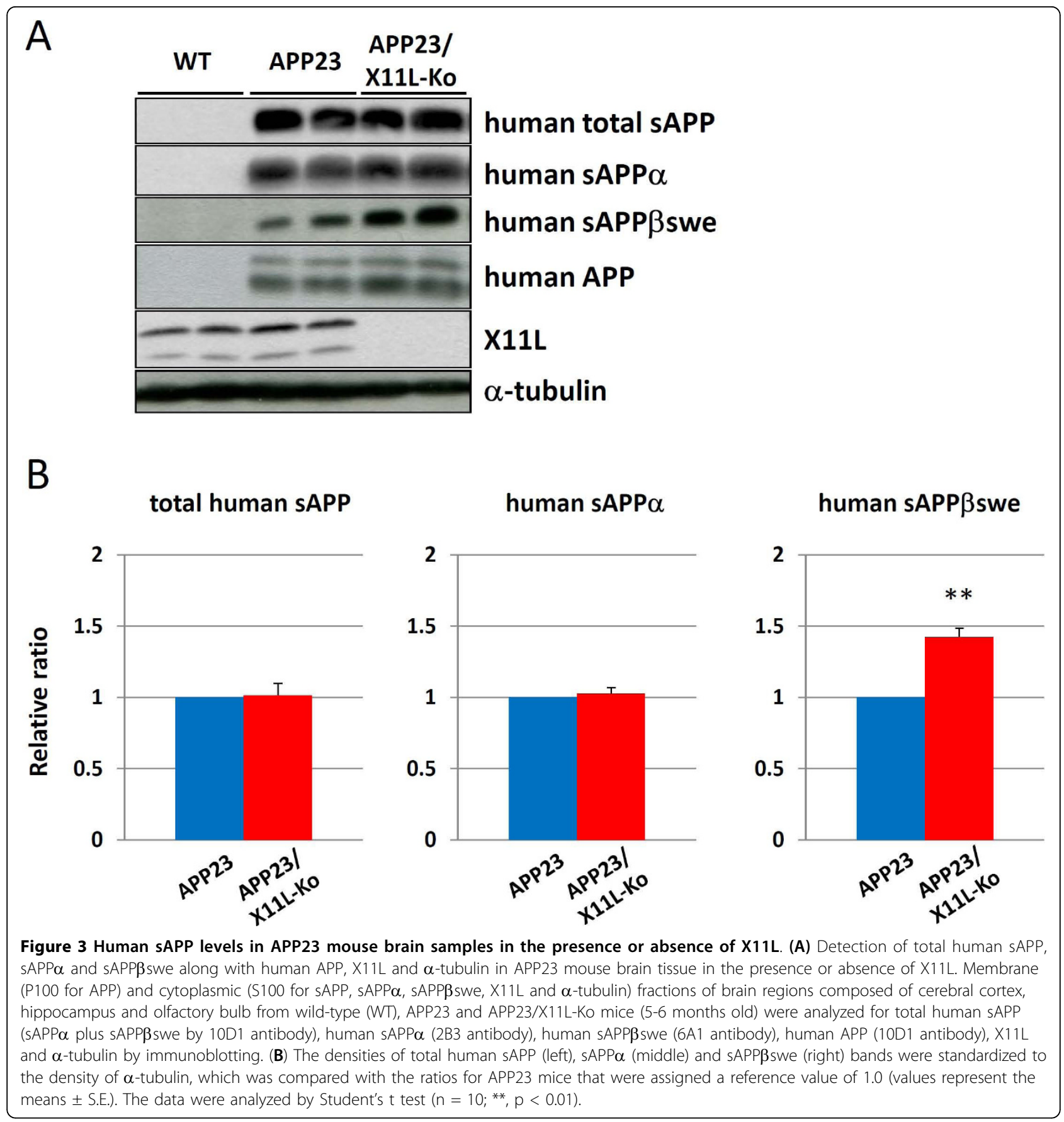

APP. One is an X11L-Ko line based on APP23 that expresses APP751swe [19]. The other, APP-ibl, is an X11L-Ko line expressing APP695swe in lower levels. We used X11L-Ko mice alone to examine the effects on the metabolism of the transgenic APP molecule because X11L-Ko mice showed a stronger increase in amyloidogenic metabolism of endogenous APP than X11-Ko. The level of this effect was similar to that in X11/X11L double-Ko mice [11]. We confirmed that, in both mice expressing higher (APP23) and lower (APP-ibl) levels of
APPswe in the absence of X11L, amyloidogenic APP metabolism increased. These results coincide well with previous reports demonstrating that X11s function to suppress $[10,11,15,16,23,24]$, but not to enhance [17], the amyloidogenic metabolism of APP (summarized in Table 1).

\section{Conclusions}

In conclusion, X11L plays an important role in suppressive regulation of APP amyloidogenic metabolism in 


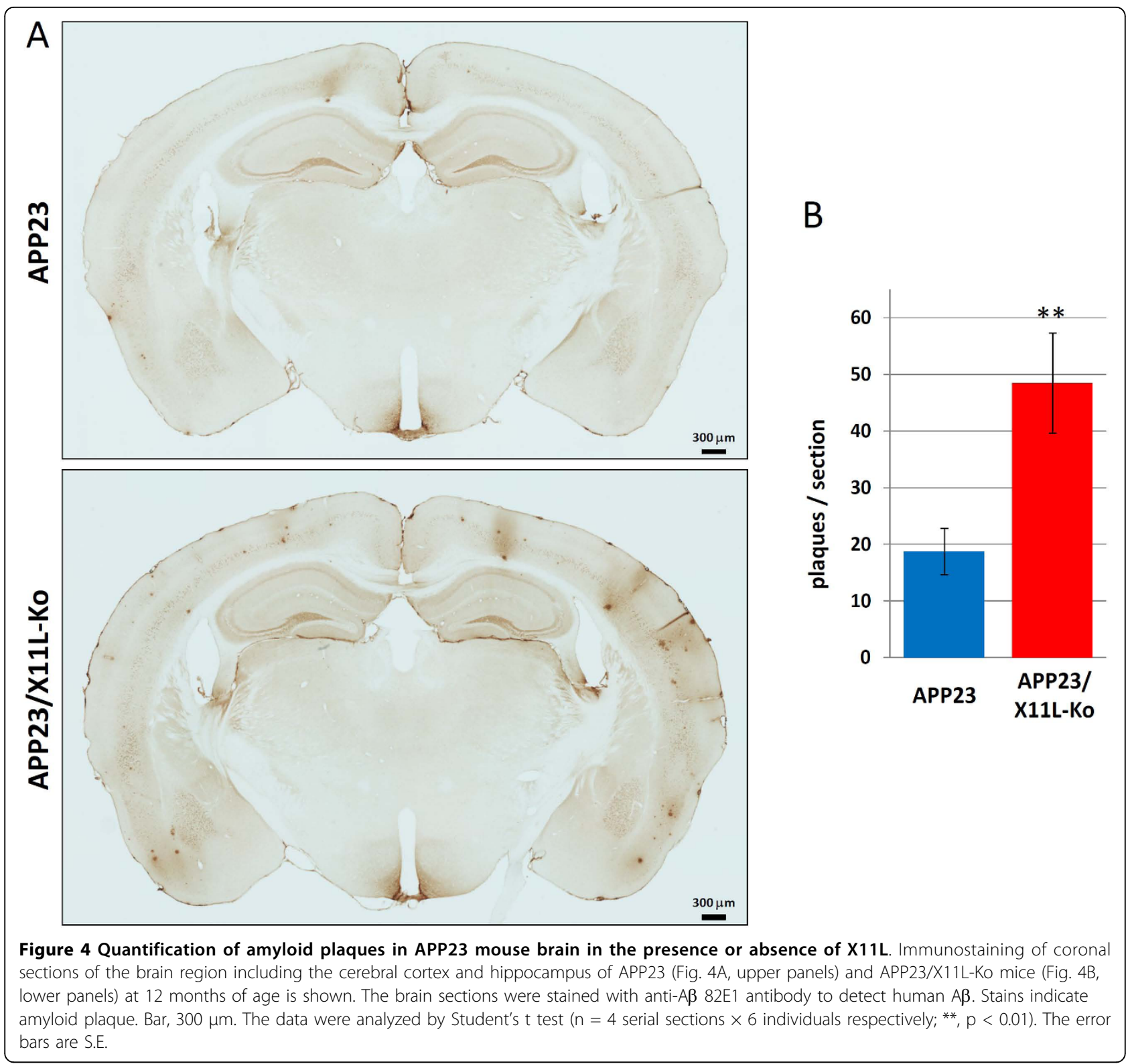

brain in vivo. The metabolic regulation of APP by X11s may provide useful targets in the development of drugs to suppress the amyloidogenic metabolism of APP in AD.

\section{Materials and methods \\ Mice}

The X11L-Ko mouse has been described [10]. The human APP751swe-tg APP23 mouse was kindly supplied from Novartis Pharma Inc. [19]. The APP-ibl transgenic mouse was generated through transduction of human APP695swe cDNA driven by the PDGF $\beta$ promotor. The DNA was injected into fertilized eggs from a BDF strain mouse, and the founder was selected by
DNA hybridization and then subjected to back-cross with the C57BL/6 strain. APP23/X11L-Ko and APP-ibl/ X11L-Ko mice were generated by mating with X11L-Ko mice generated from a C57BL/6 background [10], and heterozygous human APPswe transgenic [tg+/-, X11L-/] and $[\mathrm{tg}+/-, \mathrm{X} 11 \mathrm{~L}+/+]$ mutant mice were used for the study.

\section{Antibodies}

Mouse monoclonal antibodies to human $\mathrm{A} \beta$ 82E1 (IBL) and 6E10 (Signet COVANCE), human APP 10D1 (IBL), sAPPa 2B3(IBL), sAPP $\beta$ swe $6 A 1$ (IBL), actin (Chemicon), flotillin-1 (BD Transduction Laboratories), $\alpha$-tubulin (Zymed and Santa Cruz Biotechnologies), 


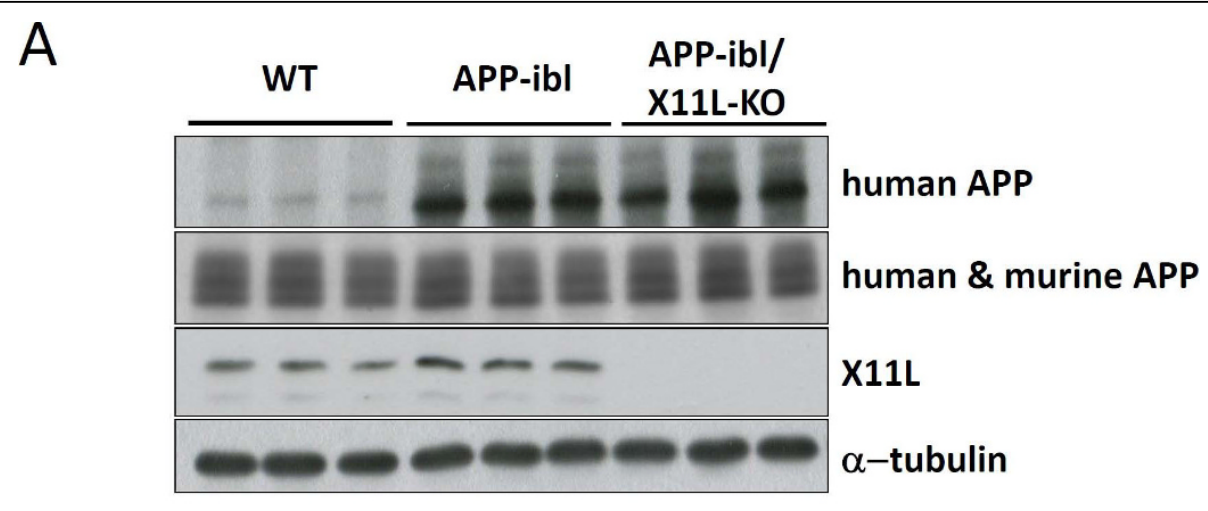

B
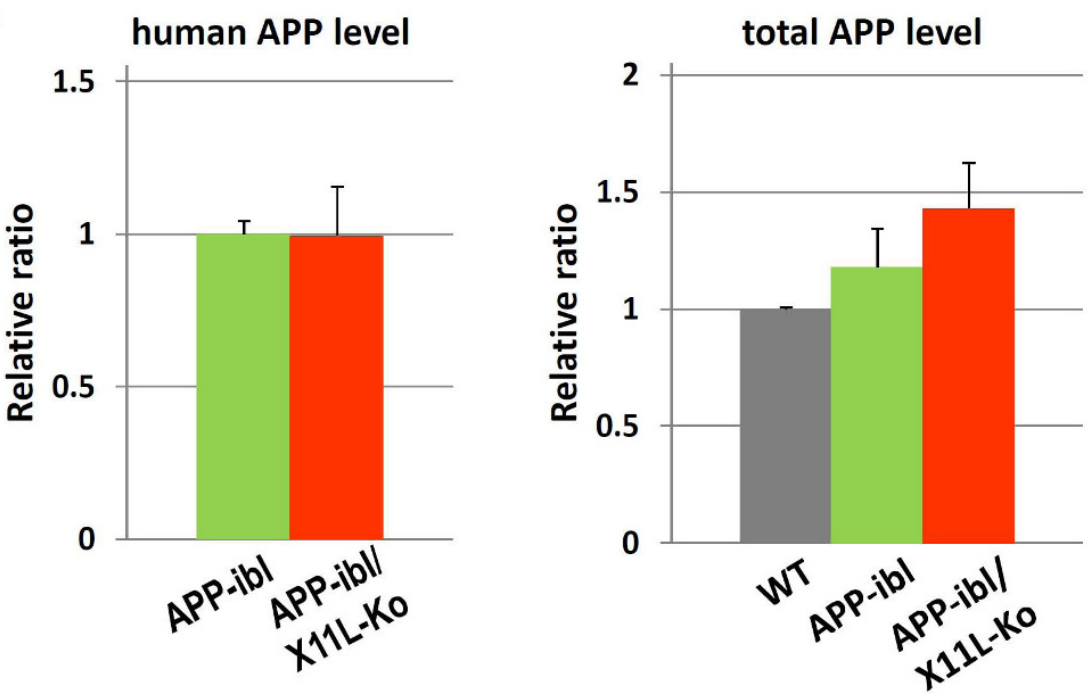

Figure 5 Expression of APP in APP-ibl mouse brain in the presence or absence of X11L. (A) Expression of human APP695swe and mouse endogenous APP695. Brain regions composed of the cerebral cortex, hippocampus and olfactory bulb from wild-type (WT), APP-ibl and APP-ibl/ X11L-Ko mice (4 months old) were homogenized in $10 \mathrm{mM}$ Tris-HCl [pH 7.9] containing 1\% (w/v) SDS, 4 M urea, complete protease inhibitor cocktail (Roche Diagnostics), and $1 \mu \mathrm{M}$ pepstatin. The lysates were analyzed by immunoblotting with anti-human APP (10D1), anti-APP (8717), anti-X11L and anti- $\alpha$-tubulin antibodies. (B) The densities of human APP695swe (left) and human plus mouse APP (right) bands were standardized to the density of $\alpha$-tubulin, which was compared with the ratios for APP-ibl mice (left) or wild-type mice (right), which were assigned a reference value of 1.0 (values represent means \pm S.E.). The data were analyzed by Student's $t$ test $(n=3)$.

and X11L/Mint2 (BD Transduction Laboratories) were purchased. Monoclonal anti-A $\beta 2 D 1$ antibodies were generated as described in [26]. Rabbit polyclonal antibodies to human A $\beta$ (IBL \#18584) and 4G8 (Signet COVANCE), and the APP cytoplasmic domain (Sigma \#8717) were purchased.

\section{Brain lysates, fractionation and immunoblotting}

Cerebral cortex, hippocampus and olfactory bulb tissue samples from each hemisphere were homogenized in eight volumes of buffer containing $10 \mathrm{mM}$ Tris- $\mathrm{HCl}$ ( $\mathrm{pH} 7.8), 1 \%(\mathrm{w} / \mathrm{v})$ SDS, $4 \mathrm{M}$ urea, complete protease inhibitor cocktail (Roche-diagnosis), and $1 \mu \mathrm{M}$ pepstatin on ice with 20 strokes of a Downce homogenizer, sonicated twice for $10 \mathrm{sec}$, and centrifuged at $15,000 \times \mathrm{g}$ for $15 \mathrm{~min}$ at $4^{\circ} \mathrm{C}$. The supernatant was used for immunoblotting to detect APP, APP CTFs and X11L. The membrane (P100) and cytosolic (S100) fractions were prepared from mouse brain hemisphere samples, including the cerebral cortex, hippocampus and olfactory bulb. The P100 fraction was solubilized as described [11]. This P100 was used to detect APP and APP CTFs, and the S100 was used to detect sAPP in immunoblot analysis. To identify each of the CTFs (C99, C89 and C83) and their respective phosphorylated forms (pC99, pC89 and $\mathrm{pC}$ (83), samples were subjected to dephosphorylation with $\lambda$ protein phosphatase as described [27] prior to immunoblotting. 


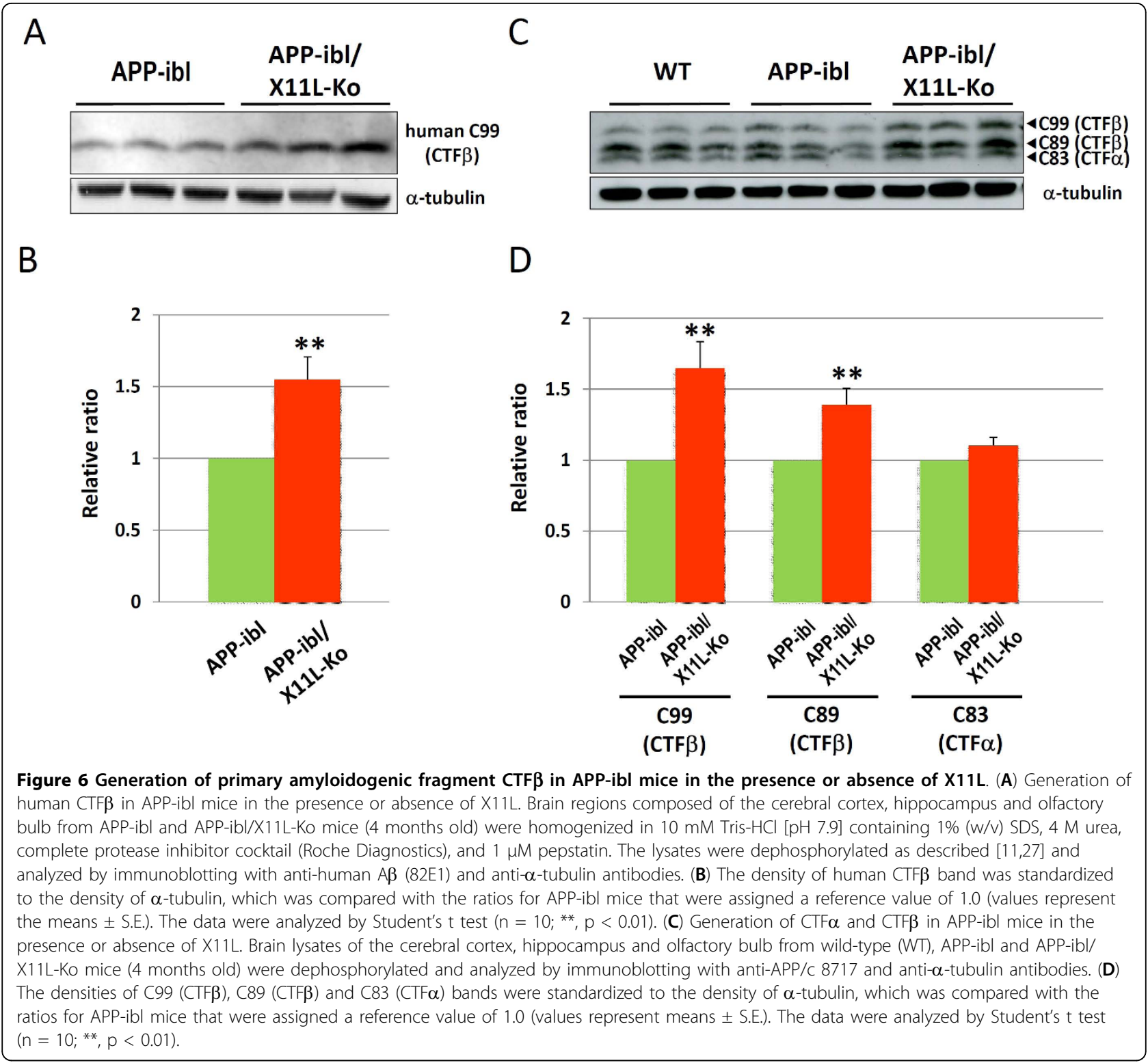

\section{Quantification of $A \beta$}

$A \beta$ quantification was performed based on the procedure described previously [10]. In brief, cerebral cortex, hippocampus and olfactory bulb samples from each hemisphere were homogenized in four volumes of Trisbuffered saline (20 mM Tris- $\mathrm{HCl}$ [pH 7.6], $137 \mathrm{mM}$ $\mathrm{NaCl}$ ) with 30 strokes of a Downce homogenizer and centrifuged at $200,000 \times \mathrm{g}$ for $20 \mathrm{~min}$ at $4^{\circ} \mathrm{C}$. The precipitate was further homogenized in nine volumes of TBS with 30 strokes and centrifuged at $100,000 \times \mathrm{g}$ for $20 \mathrm{~min}$ at $4^{\circ} \mathrm{C}$. One volume of $6 \mathrm{M}$ guanidine chloride in TBS was then added to the precipitate, sonicated for $10 \mathrm{sec}$ twice, and allowed to stand for $1 \mathrm{~h}$ at room temperature. The samples were then centrifuged at 130,000 $\times \mathrm{g}$ for $20 \mathrm{~min}$ at $4^{\circ} \mathrm{C}$. The supernatant was assayed with sandwich enzyme-linked immunosorbent assay (ELISA) kits (IBL 27714 for human $A \beta 40$ and IBL 27712 for human $A \beta 42$ ) following dilution with $\mathrm{PBS}$ containing $1 \%(\mathrm{w} / \mathrm{v})$ of BSA and $0.05 \%(\mathrm{v} / \mathrm{v})$ of Tween 20 as follows: 24-fold for $A \beta 40$; 12 -fold for $A \beta 42$ of APP-ibl mice; 500-fold for $A \beta 40$; and 100-fold for $A \beta 42$ of APP23 mice.

\section{Immunohistochemistry}

Frozen mouse brain tissue sections $(25-\mu \mathrm{m}$ thick) were immunostained by either (i) incubation for $1 \mathrm{~h}$ in PBS containing $5 \%(\mathrm{v} / \mathrm{v})$ normal horse serum with mouse monoclonal antibodies, or (ii) incubation for $1 \mathrm{~h}$ in PBS containing $5 \%(\mathrm{v} / \mathrm{v})$ normal goat serum with rabbit polyclonal antibodies for blocking prior to overnight 

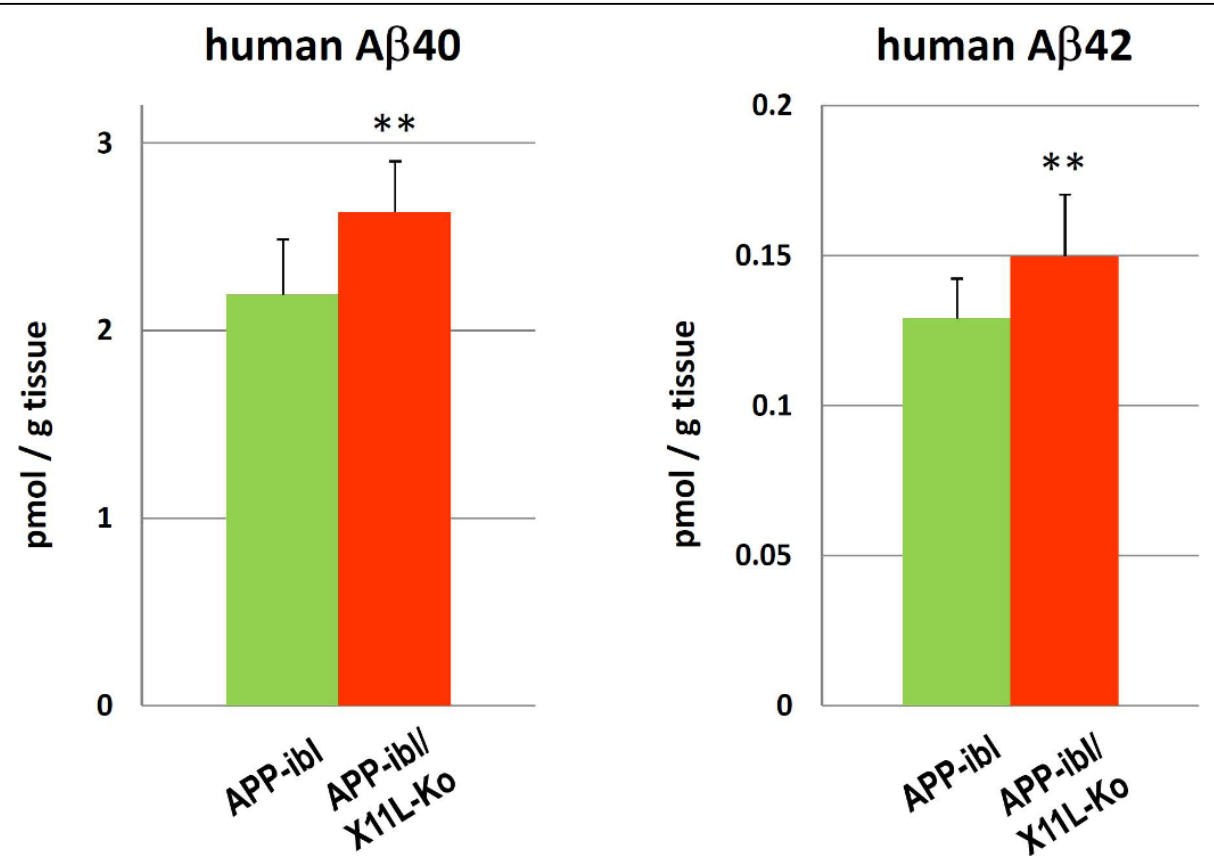

Figure 7 Human $\mathbf{A} \boldsymbol{\beta}$ levels in APP-ibl mouse brain in the presence or absence of X11L. Quantification of human $A \beta 40$ (left) and $A \beta 42$ (right) in the cerebral cortex, hippocampus and olfactory bulb from APP-ibl and APP-ibl/X11L-Ko mice (5-6 months old) was performed by sELISA, with concentrations normalized to tissue weight. The data were analyzed by Student's t test. Statistical significance is indicated with asterisks $\left(n=10 ;{ }^{* *}, p<0.01\right)$. The error bars are S.E.

incubation with primary antibody. For $A \beta$ staining, tissue sections were incubated in PBS containing $0.3 \%(\mathrm{v} /$ v) $\mathrm{H}_{2} \mathrm{O}_{2}$ for $30 \mathrm{~min}$ and washed in PBS three times. The sections were then incubated in PBS containing 70\% (w/ v) formic acid for 1 min prior to blocking. After washing the sections with PBS three times for $10 \mathrm{~min}$, the sections were incubated with horse anti-mouse IgG or goat anti-rabbit IgG antibodies conjugated with biotin (Vector Laboratories), followed by $\mathrm{ABC}$ complex. Peroxidase activity was revealed using diaminobenzidine $(\mathrm{DAB})$ as the chromogen. The sections were viewed using a BZ9000 microscope (KEYENCE, Osaka, Japan).

\section{Additional material}

Additional file 1: Supplemental Figures. Supplemental Figures S1 and S2

\section{Abbreviations}

A $\beta$ : $\beta$-amyloid; APP: Alzheimer's $\beta$-amyloid precursor protein; APPswe; APP carrying Swedish type mutation; SELISA: sandwich enzyme-linked immunosorbent assay; mAPP: mature APP; BACE: $\beta$-site cleaving enzyme; PS: presenilin; CTF $\alpha$ : the carboxyl-terminal fragment of APP cleaved at the $\alpha$ site; CTF $\beta$ : the carboxyl-terminal fragment of APP cleaved at the $\beta$-site; sAPP: large extracellular $\mathrm{N}$-terminal domain truncated the $\alpha$-site (SAPP $\alpha$ ) and/or the $\beta$-site (SAPP $\beta$ ); DRM: detergent resistant membrane; $X 11$ s: $X 11$ proteins (X11, X11L plus X11L2); X11L: X11-like.

\section{Acknowledgements}

This study was supported in part by a Grant-in-aid for Scientific Research from the MEXT (20390018, 21113601, and 22659011 for TS). TM is a recipient of a research fellowship from the JSPS for Young Scientists. We thank Drs. Nobuhisa Iwata (RIKEN BSI) and Maho Morishima (Hokkaido University) for their technical advice and discussion. We also thank Novartis Pharma Inc. for supplying the APP23 mice.

\section{Author details}

'Laboratory of Neuroscience, Graduate School of Pharmaceutical Sciences, Hokkaido University, Kita12-Nishi6, Kita-ku, Sapporo 060-0812, Japan. ${ }^{2}$ Immuno-Biological Laboratories Co. Ltd. (IBL), Mikasa Laboratory, Okayama 440-22, Mikasa 068-2165, Japan. ${ }^{3}$ Immuno-Biological Laboratories Co. Ltd. (IBL), Naka 1091-1, Fujioka 375-0005, Japan. ${ }^{4}$ Creative Research Institute Sousei, Hokkaido University, Kita21-Nishi10, Kita-ku, Sapporo 011-0021, Japan. ${ }^{5}$ Laboratory of Neuronal Cell Biology, Graduate School of Pharmaceutical Sciences, Hokkaido University, Kita12-Nishi6, Kita-ku, Sapporo 060-0812, Japan.

\section{Authors' contributions}

MK, MS, TM, SH and YS carried out all of the experiments. Gl, NT and MM produced the APP-ibl transgenic mouse line. HT, TY and TS participated in the design of the study and the writing of the manuscript. TS conceived the study and was the primary author of the manuscript. All authors read and approved the final manuscript.

\section{Competing interests}

The authors declare that they have no competing interests.

Received: 11 May 2010 Accepted: 15 September 2010

Published: 15 September 2010

\section{References}

1. Tomita S, Ozaki T, Taru H, Oguchi S, Takeda S, Yagi Y, Sakiyama S, Kirino Y, Suzuki T: Interaction of a neuron-specific protein containing PDZ 
domains with Alzheimer's amyloid precursor protein. J Biol Chem 1999, 274:2243-2254

2. Hase M, Yagi Y, Tomita S, Sumioka A, Hori K, Miyamoto K, Sasamura T, Nakamura M, Matsuno K, Suzuki T: Expression and characterization of the Drosophila X11-like/Mint protein during neural development. J Neurochem 2002, 81:1223-1232.

3. Vishnu S, Hertenstein A, Betschinger J, Knoblich JA, Gert de Couet H, Fishbach KF: The adaptor protein X11Lalpha/Dmint1 interacts with the PDZ-binding domain of the cell recognition protein Rst in Drosophila. Dev Biol 2006, 289:296-307.

4. Foletti $\mathrm{D}$, Prekeris $\mathrm{R}$, Scheller RH: Generation and maintenance of neural polarity mechanisms of transport and targeting. Neuron 1999, 23:641-644.

5. Miller CC, McLoughlin DM, Lau KF, Tennant ME, Rogelj B: The X11 proteins, Abeta production and Alzheimer's disease. Trends Neurosci 2006 29:280-285.

6. Borg JP, Yang Y, De Taddeo-Borg M, Margolis B, Turner RS: The X11alpha protein slows cellular amyloid precursor protein processing and reduces A 340 and Aß42 secretion. J Biol Chem 1998, 273:14761-14766.

7. Tanahashi $H$, Tabira $T: X 11 L 2$, a new member of the $X 11$ protein family, interacts with Alzheimer's $\beta$-amyloid precursor protein. Biochem Biophys Res Commun 1999, 255:663-667.

8. Haass C, Selkoe DJ: Soluble protein oligomers in neurodegeneration: lessons from the Alzheimer's amyloid $\beta$-peptide. Nat Rev Moll Cell Biol 2007, 2:101-112.

9. Thinakaran G, Koo E: Amyloid precursor protein trafficking, processing, and function. J Biol Chem 2008, 283:29615-29619.

10. Sano Y, Syuzo-Takabatake A, Nakaya T, Saito Y, Tomita S, Itohara S, Suzuki T: Enhanced amyloidogenic metabolism of the amyloid $\beta$-protein precursor in the X11L-deficient mouse brain. J Biol Chem 2006, 281:37853-37860.

11. Saito $Y$, Sano $Y$, Vassar R, Gandy S, Nakaya T, Yamamoto T, Suzuki T: X11 proteins regulate the translocation of amyloid $\beta$-protein precursor (APP) into detergent-resistant membrane and suppress the amyloidogenic cleavage of APP by $\beta$-site-cleaving enzyme in brain. J Biol Chem 2008, 283:35763-35771.

12. Suzuki T, Nakaya T: Regulation of amyloid $\beta$-protein precursor by phosphorylation and protein interactions. J Biol Chem 2008, 283:29633-29637.

13. Cordy JM, Hussain I, Dingwall C, Hooper M, Turner AJ: Exclusively targeting $\beta$-secretase to lipid rafts by GPI-anchor addition up-regulates $\beta$-site processing of the amyloid precursor protein. Proc Natl Acad Sci USA 2003, 100:11735-11740.

14. Ehehalt $R$, Keller $P$, Haass $C$, Thiele $C$, Simons $K$ : Amyloidogenic processing of the Alzheimer $\beta$-amyloid precursor protein depends on lipid rafts. J Cell Biol 2003, 160:113-123.

15. Lee JH, Lau KF, Perkinton MS, Standen CL, Shemilt SJ, Mercken L, Cooper JD, McLoughlin DM, Miller CC: The neuronal adaptor protein $\mathrm{X} 11 \alpha$ reduces $A \beta$ levels in the brains of Alzheimer's APPswe Tg2576 transgenic mice. J Biol Chem 2003, 278:47025-47029.

16. Lee JH, Lau KF, Perkinton MS, Standen CL, Rogelj B, Falinska A, McLoughlin DM, Miller CC: The neuronal adaptor protein $X 11 \beta$ reduces amyloid $\beta$-protein levels and amyloid plaque formation in the brains of transgenic mice. J Biol Chem 2004, 279:49099-49104.

17. Ho A, Liu X, Sudhof TC: Deletion of Mint proteins decreases amyloid production in transgenic mouse models of Alzheimer's disease. $J$ Neurosci 2008, 28:14392-14400.

18. Citron M, Oltesdorf T, Haass C, McConlogue L, Hung AY, Seubert, VigoPelfrey $C$, Lieberburg I, Selkoe DJ: Mutation of the $\beta$-amyloid precursor protein in familial Alzheimer's disease $\beta$-protein production. Nature 1992, 360:672-674.

19. Struchler-Pierrat C, Abramowski D, Duke M, Wiedehold KH, Mistl C, Rothacher S, Ledemann B, Burki K, Frey P, Paganetti PA, Waridel C, Calhoun ME, Jucker M, Probst A, Staufenbiel M, Sommer B: Two amyloid precursor protein transgenic mouse models with Alzheimer disease-like pathology. Proc Natl Acad Sci USA 1997, 94:13287-13292.

20. Borchelt DR, Ratovitski T, van Lare J, Lee MK, Gonzales V, Jenkins NA, Copeland NG, Price DL, Sisodia SS: Accelerated amyloid deposition in the brains of transgenic mice coexpressing mutant presenilin 1 and amyloid precursor proteins. Neuron 1997, 19:939-945.

21. Shankar GM, Li S, Methta TH, Garcia-Munoz A, Shepardson NE, Smith I, Brett FM, Farrell MA, Rowan MJ, Lemere CA, Regan CM, Walsh DM,
Sabatini BL, Selkoe DJ: Amyloid- $\beta$ protein dimers isolated directly from Alzheimer's brain impair synaptic plasticity and memory. Nat Med 2008, 14:837-842.

22. Rovelet-Leurux A, Hannequin D, Raux G, Le Meur N, Laquerriere A, Vital A, Dumanchin C, Feuillette S, Brice A, Vercelletto M, Dubas F, Frebourg T, Campion D: APP locus duplication causes autosomal dominant earlyonset Alzheimer disease with cerebral amyloid angiopathy. Nat Genet 2006, 38:24-26

23. Saluja I, Paulson H, Gupta A, Turner SR: X11 $\alpha$ haploinsufficiency enhances $A \beta$ amyloid deposition in Alzheimer's disease transgenic mice. Neurobiol Dis 2009, 36:162-168.

24. Michell JC, Ariff BB, Yates DM, Lau KF, Perkinton MS, Rogelj B, Stephenson JD, Miller CCJ, McLoughlin DM: X11 $\beta$ rescues memory and long-term protention deficitis in Alzheimer's disease APPswe Tg2576 mice. Human Mol Gennet 2009, 18:4492-4500.

25. Vetrivel KS, Zhang Y-w, Xu H, Thinakaran G: Pathological and physiological functions of presenilins. Mol Neurodegen 2006, 1:4.

26. Tomita S, Kirino Y, Suzuki T: Cleavage of Alzheimer's amyloid precursor protein (APP) by secretases occurs after O-glycosilation of APP in the protein secretory pathway. J Biol Chem 1998, 273:6277-6284.

27. Nakaya T, Suzuki T: Role of APP phosphorylation in FE65-dependent gene transactivation mediated by AICD. Genes Cell 2006, 11:633-645.

doi:10.1186/1750-1326-5-35

Cite this article as: Kondo et al:: Increased amyloidogenic processing of transgenic human APP in X11-like deficient mouse brain. Molecular Neurodegeneration 2010 5:35.

\section{Submit your next manuscript to BioMed Central and take full advantage of:}

- Convenient online submission

- Thorough peer review

- No space constraints or color figure charges

- Immediate publication on acceptance

- Inclusion in PubMed, CAS, Scopus and Google Scholar

- Research which is freely available for redistribution
Ciomed Central 